\title{
Algorithm Reliability of Kalman Filter Coefficients Determination for Low-Intensity Electroretinosignal
}

\author{
Pavlo Tymkiv \\ Department of Biotechnical System \\ Ternopil Ivan Puluj National Technical University \\ Ternopil, Ukraine \\ t_pavlo_o@ukr.net, ORCID: 0000-0003-1212-3107
}

\author{
Yuriy Leshchyshyn \\ Department of Biotechnical System \\ Ternopil Ivan Puluj National Technical University \\ Ternopil, Ukraine \\ leshchishin@gmail.com
}

\begin{abstract}
The estimation method of the algorithm reliability for determination of the Kalman filter coefficients for lowintensity electroretinosignal (ERS) processing is constructed. The estimation method of the algorithm reliability is obtained by modifying the Neumann-Pearson criterion. This allowed using of receiver operating characteristic analysis (ROC-analysis) and determination of the area under ROC-curve characteristics (AUC-characteristics) of the proposed algorithm.
\end{abstract}

Keywords-electroretinography, electroretinosignal, Kalman filter, Neyman-Pearson criterion, classifier, ROC-analysis, AUC

\section{INTRODUCTION}

A modified electroretinography study of the human body is used in assessing the risk of neurotoxicity [1], but it is necessary to ensure high resolution and accuracy of the processing of the resulting low-intensity ERS [2] and [3]. In the writings of Tkachuk R.A. and Yavorskyy B.I. [4] and [5] on the heuristic basis the use of the Kalman filter was substantiated and the method of the sequential selection of the coefficients of the computational recursive structure of the 2-nd order as a mathematical model of the standard pregenerated electroretinogram (ERG), based on the mean-square criterion, was used to ensure the necessary accuracy of the reproduction of a useful ERS.

In [4] and [5], the algorithm for the sequential selection of coefficients (direct directed bursts, hereinafter referred to as A0) of the mathematical model is used. In [6], [7] and [8], we propose an algorithm (hereinafter referred to as A1) to determine these coefficients, by direct directed fetching in several iterations with the change of the folding step. Therefore, in determining the effectiveness of the proposed algorithm, it is necessary to assess the reliability of A1 and A0 and the possibility of further application for the synthesis of the Kalman filter in the processing of low-intensity ERS.

\section{ADAPTATION OF THE NEYMAN-PIRSON CRITERION FOR ESTIMATION THE ACCURACY OF A0 AND A1}

Investigation of low-intensity ERS is associated with the problem of detecting a small useful signal in a mixture with noise [10]. The given problem in ophthalmological diagnostic systems (in particular, in CALYPSO, DKZO-01 systems and others) is solved by the method of averaging a certain $(N)$ number of registration mixtures, resulting in the variance of noise decreases once and with the increase in the number of registrations, the value of the average signal-noise mixture goes to values of the ERS.

However, this method of treatment is associated with inconvenience and fatigue of the patient [9] and [10], and for low-intensity ERS, the number of $N$ can be dozens of registrations, which is not always possible. Low-intensity ERS selected from a bioobject can be considered as a mixture of useful electroretinosignal and interference:

$$
x(i \Delta t)=s(i \Delta t)+n(i \Delta t)
$$

where, $s(i \Delta t)$ - useful low-intensity ERS, $n(i \Delta t)$ - additive white Gaussian noise, $\Delta t$ - step of sampling $(\Delta t=1 / 2 f$, $f$ - frequency of sampling of low-intensity ERS with the conditions of the theorem of Kotelnikov), and $i$ - reference number. To evaluate $\mathrm{A} 0$ and $\mathrm{A} 1$ we will perform a statistical test and compare the reliability of the results of work. Validation of reliability will be carried out on the basis of the Bayesian concept of probability theory (Fig. 1), on the basis of which a criterion for justifying the choice (approval) of the solution is constructed.

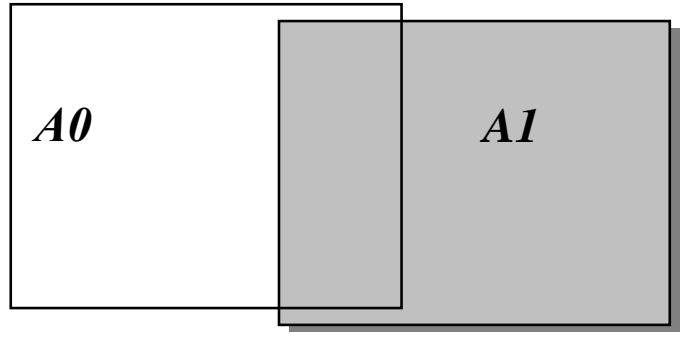

Fig. 1. Geometric interpretation of the binary classification of two alternative methods for determining the coefficients of the Kalman filter (A0 - prototype method, A1 - advanced method)

Under the initial hypothesis $H_{0}$ (zero-hypothesis) we mean acceptance $\mathrm{A} 0$, and under the alternative hypothesis $H_{l}$ - we understand acceptance of A1. 
That is, on the basis of the Bayesian concept of probability theory:

$$
P(B) P(C \mid B)=P(C) P(B \mid C)
$$

where, $P(B)$ is the probability of the test result A0, $P(C)-$ the probability of the test result $\mathrm{A} 1, P(C \mid B)$ - the conditional probability of A1 given $\mathrm{A} 0, P(B \mid C)$ - the conditional probability of A0 given A1.

By analogy with the known interpretations of conditional probabilities, we introduce the following names: $P(B \mid C)$ - the error of the first kind, $P(C \mid B)$ - a error of the second kind.

Since the a priori probability of these errors is unknown, so let's use the Neyman-Pearson criterion which maximizes the probability of detection (probability of choosing a more reliable algorithm $\left(P_{d}\right)$ ) with a predetermined value of the probability of a false alarm (probability of a false choice of a less reliable algorithm $\left(P_{f a}\right)$ ).

Also, the probability of a false choice of a less reliable $P_{f a}$ algorithm allows you to capture negative effects or losses when making a wrong decision.

\section{APPLICATION METHOD OF THE VALIDATION AND ROC- ANALYSIS TO A0 AND A1}

By means of simulation, we obtain statistics of low-intensity ERS $x(t)$ with normal probability distribution (Fig. 2 and Fig. 3) describe in [11], [12], [13] and [14]. In the study, additive compatibility (1) was used for the ERS model, $s(i \Delta t)$ - a useful signal, $n(i \Delta t)$ - noise, a discrete accident with a normal function of the density of distribution of its values (with zero mathematical expectations and variance unit equal 1, normrnd function from Matlab) was used [12]. Apply it to obtain the test statistics of the Kalman filter work, the coefficients of which are determined by algorithms A0 and A1.

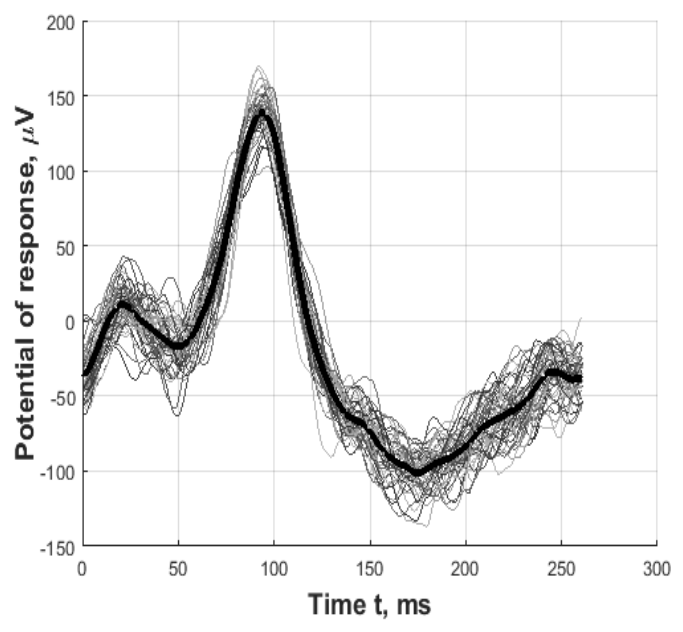

Fig. 2. Ensemble of simulated low-intensity ERS: an ensemble of simulated low-intensity ERS prototyping method (number of simulated ERS - 50, the thick line - mathematical expectation).

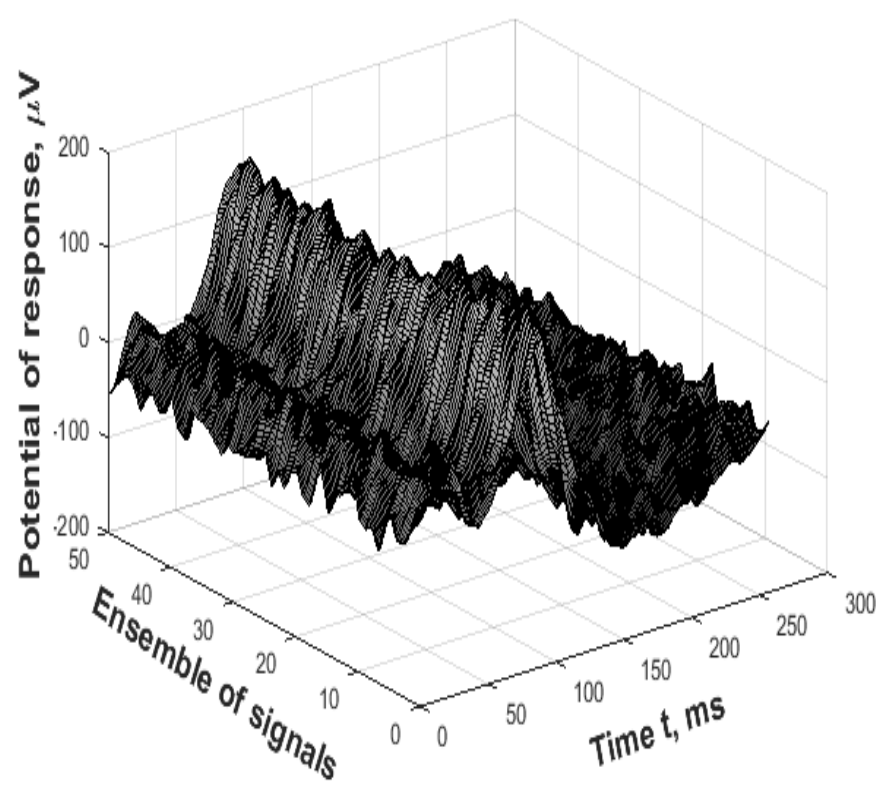

Fig. 3. Ensemble of simulated low-intensity ERS: an ensemble of simulated low-intensity ERS with an improved method

Also, defined the mathematical expectation of the dispersion obtained with the algorithm A1 of the ensemble of the ERS (Fig. 4).

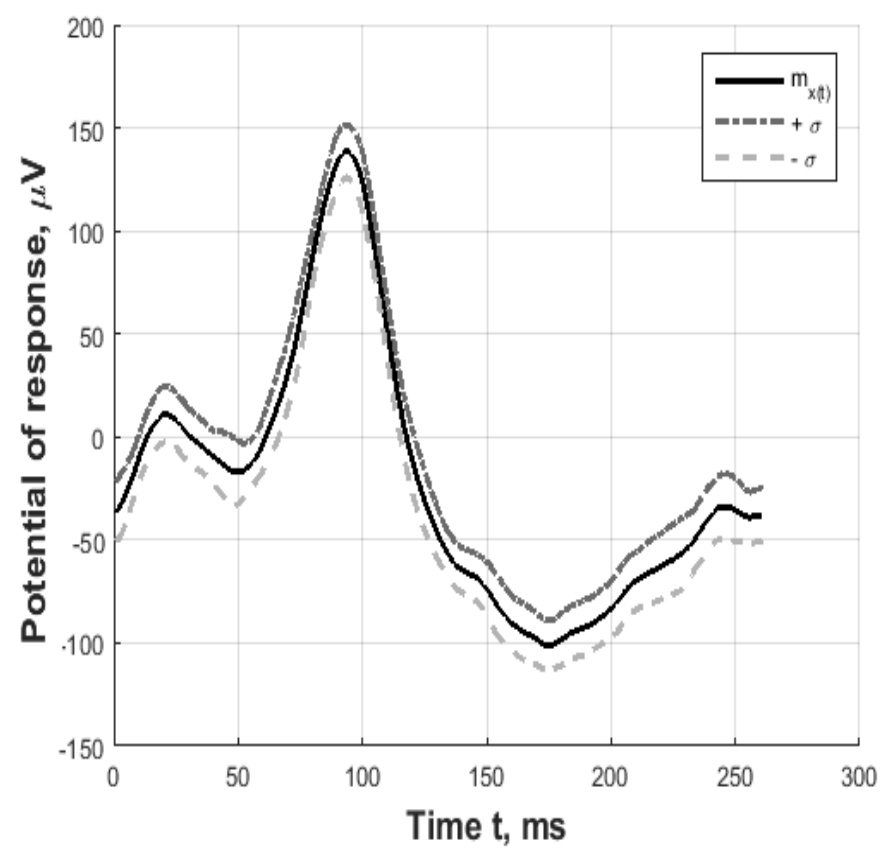

Fig. 4. Graphical representation of the moments of the 1 st order (mathematical expectation and variance) for the ensemble of simulationmodeled low-intensity ERS by the improved method 
Density distribution of probabilities of test statistics obtained is shown in Fig. 5.

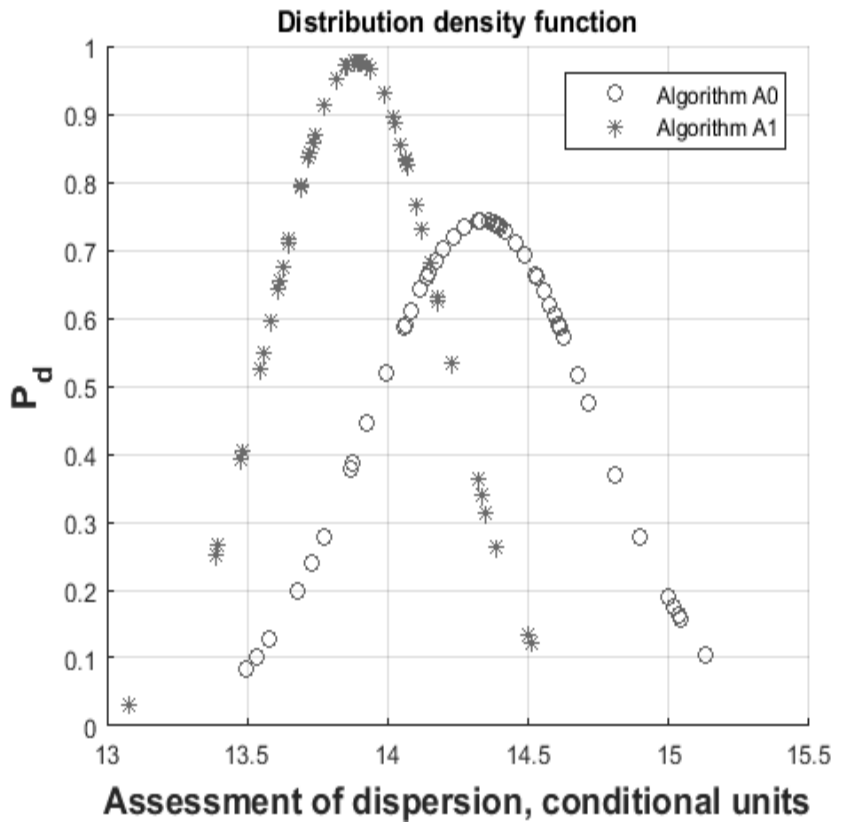

Fig. 5. The function of distribution density A0 and A1

We apply the adapted Neumann-Pearson criterion to the test statistics obtained.

To construct a criterion for choosing a method for determining coefficients, as is accepted in the theory of statistical choice of decisions, the important is the lack of a priori information about the approval of the decision to select a method. Namely, the decision to choose a method is carried out according to a certain criterion, in particular, according to the Neumann-Pearson criterion, which is used when there is no apriority information about the choice of the method.

By the Neumann-Pearson criterion and the probability density distribution of the test statistic of low-intensity ERS $W_{0}(q)$, we set the probability of a false determination of the method for determining the coefficients of $P_{f a}$, which determines the losses from making the wrong decision. And as shown in Fig. 5, it is interpreted as the probability that the value of the test statistic $q(t)$ exceeds a certain threshold value of the threshold $\gamma$, which leads to an erroneous decision about the choice of the method [15] and [16].

$$
P_{f a}=P[q(t) \geq \gamma]=\int_{\gamma}^{\infty} W_{0}(q) d q
$$

By the probability distribution density of the test statistic $W_{l}(q)$ we calculate the probability of the correct choice of the method for determining the coefficients $P_{d}$

$$
P_{d}=\int_{\gamma}^{\infty} W_{1}(q) d q
$$

This is interpreted as the probability that the value of the test statistic $q(t)$ exceeds a certain threshold value of the threshold $\gamma$, and a correct decision about the choice of the method will be made.

By the Neumann-Pearson criterion, the probability of a false determination of the $P_{f a}$ disorder is given, and the probability of the correct determination of the $P_{d}$ disorder is determined:

$$
\begin{gathered}
P_{f a}=1-\Phi\left(\frac{\gamma-m_{o}}{\sqrt{D_{0}}}\right) \\
P_{d}=1-\Phi\left(\frac{\gamma-m_{1}}{\sqrt{D_{1}}}\right)
\end{gathered}
$$

where, $\Phi(\bullet)$ - the Gauss function $m_{l}-$ is the mathematical expectation of the ensemble of low-intensity ERS using the algorithm A1; $D_{1}$ - is the variance of the values of the ensemble of low-intensity ERS using the algorithm A1; $m_{0}-$ is the mathematical expectation of the ensemble of low-intensity ERS using the algorithm A0; $D_{0}$ - is the variance of the values of the ensemble of low-intensity ERS using the algorithm A0.

By the given probability of a false definition of $P_{f a}$, we define the thresholds of the level $\gamma$ by the expression:

$$
\gamma=\sqrt{D_{0}} \Phi^{-1}\left(1-P_{f a}\right)+m_{0}
$$

The characteristics of the accuracy of the choice of A0 or A1 are the dependence of the probability of a correct determination of $P_{d}$ from the deviation coefficient [16], with a fixed probability of a false choice of the $P_{f a}$ method $\left(P_{f a}=0.1\right.$; $\left.P_{f a}=0.01 ; P_{f a}=0.001 ; P_{f a}=0.0001\right)$. The corresponding graphs are shown in Fig. 6. On the other hand, according to [16], the problem of detecting a constant signal (in our case, the problem of choosing A0 or A1) can be generalized and considered as a task of distinguishing two constant signals in the presence of Gaussian noise. This problem is called meanshifted Gauss-Gauss. Thus, one or another hypothesis is taken depending on the shift of the average statistic value. For such a determinant we will determine the deviation factor $\left(K_{\text {deviation }}\right)$ [16] by the formula:

$$
K_{\text {deviation }}=\frac{\left(\mu_{1}-\mu_{0}\right)^{2}}{\sigma_{1}^{2}}
$$


Determine the deviation factor $\left(K_{\text {deviation }}\right)$ for the test statistics for A0 and A1 by the improved method depicted in Fig. 5. (see Fig. 6).

In this way, the characteristics of choosing the method for determining the coefficients are calculated.

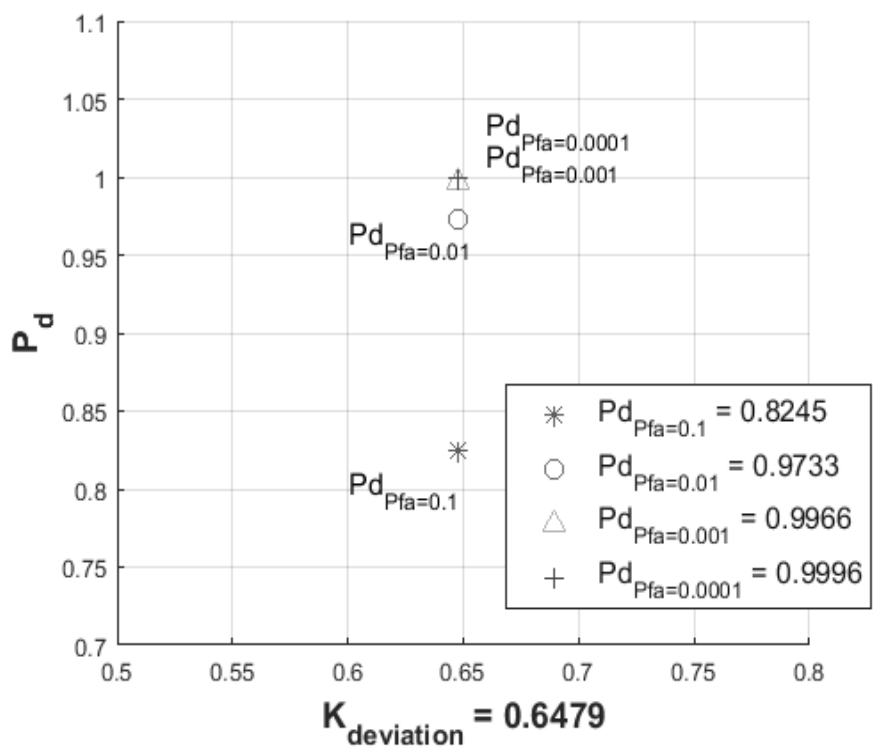

Fig. 6. Value probability of choosing a more reliable algorithm when $K_{\text {deviation }}$ is installed

Calculate the probability of correct determination of the choice of algorithm when determining the probability of a false choice of $P_{f a}$ (Fig. 7). Use the expression:

$$
P_{d}=P\left[P^{-1}\left(P_{f a}\right)-\frac{m_{1}-m_{0}}{\sqrt{D_{1}}}\right]
$$

The calculation of $P_{d}$ is shown in Fig. 7

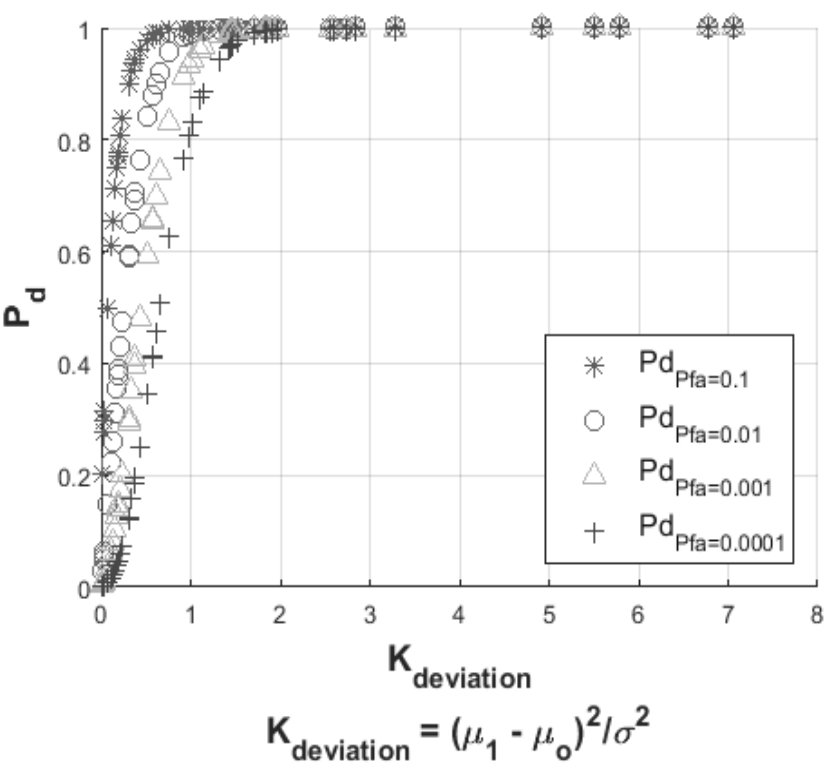

Fig. 7. Schedule depending on probability of detection on $K_{\text {deviation }}$

Based on the results of the binary classification according to the modified Neyman-Pearson criterion, we determine the dependence of the number of correctly classified positive decision-making results for $\mathrm{A} 1$ and $\mathrm{A} 0$ on the number of incorrectly classified false results. To do this we use the ROCanalysis. In terms of ROC-analysis, the former are called a truly positive set, and the second is a false negative set. It is assumed that the classifier has some parameter, changing, we get a certain distribution. This parameter is often referred to as a threshold or cut-off value.

Quantitative interpretation of ROC-analysis gives AUC (area under ROC-curve) - the area is limited by the ROC curve and the axis of the fraction of false positive classifications (Fig. 8 and Fig. 9). The higher the AUC, the more qualitative the classifier and the method is more reliable. In this case, the value of 0.5 demonstrates the unsuitability of the chosen classification method (corresponding to the usual guesswork). 


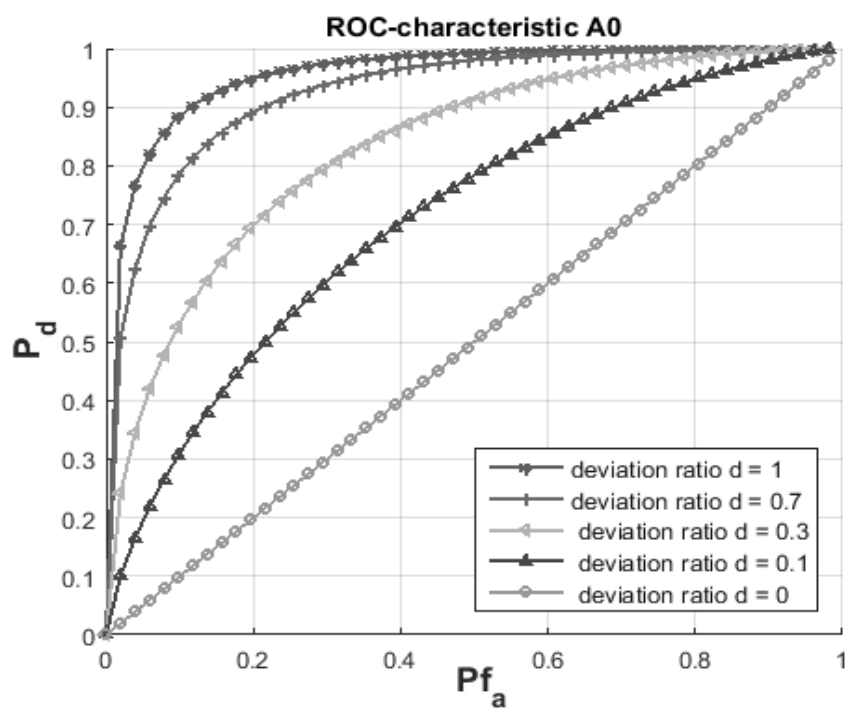

Fig. 8. ROC-curves and AUC for A0

Define ROC-characteristics for A1 by analogy with A0 (Fig. 9)

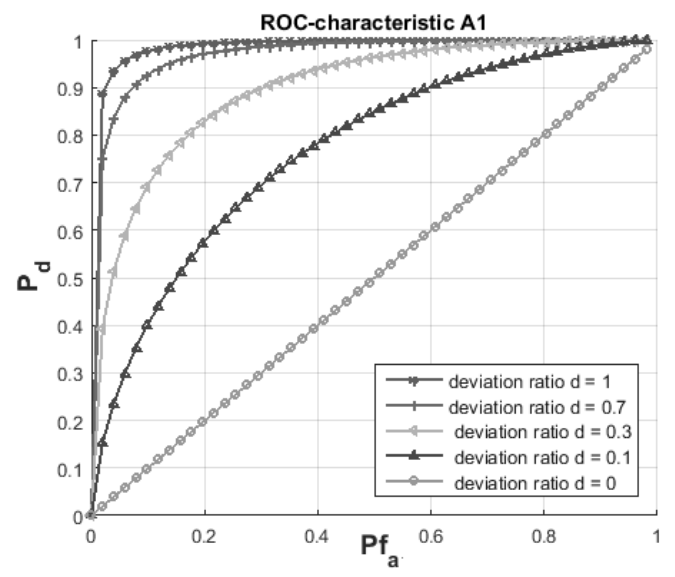

Fig. 9. ROC-curves and AUC for A1

The results of the ROC-analysis shown in Fig. 9 for the A1 algorithm have the largest area and approach to 1 (see the upper left corner of the graph) than the graphs of the algorithm A0 (on the Fig. 8).

\section{CONCLUSION}

The estimation method of the algorithm reliability for determination of the Kalman filter coefficients for lowintensity ERS processing is constructed. This method is used to estimate algorithm reliability of the prototype algorithm A0 and the proposed algorithm A1.

Validation of reliability is based on the Bayesian concept of probability theory, and the criterion for the approval of the solution is constructed - the Neumann-Pearson criterion. According to which, when determining the probability of a false choice $\left(P_{f a}=0,1 ; P_{f a}=0,01 ; P_{f a}=0,001 ; P_{f a}=0,0001\right)$, the probability of the correct choice was $P_{d}=0.8245$; $P_{d}=0.9733 ; P_{d}=0.9966 ; P_{d}=0.9996$ respectively.

The results of the ROC-analysis and the AUC parameter showed a higher reliability of the proposed algorithm A1. The resulting functional dependence of the AUC makes it possible to plan scientific experiments and investigate the use of the Kalman filter for the processing of low-intensity ERS.

\section{REFERENCES:}

[1] Environmental Health Criteria 223. Neurotoxicity Risk Asessment For Human Health: Principles And Approaches.

[2] Finkelstein D., Gouras P., Hoff M, Human electroretinogram near the absolute threshold of vision, Investigative Ophthalmology, vol. 7, pp.214-218, April 1963.

[3] Hecht S. Energy, Quanta and Vision. Journal of General Physiology, pp.819-840, July 1942.

[4] Tkachuk R.A., Optymizaciya retynografichnoyi systemy dlya vyyavlennya pryhovanogo biologichnogo vplyvu na organizm lyudyny "Optyko-elektronni informacijno-energetychni texnologiyi”, vol. 2., pp.145-152, 2009.

[5] Tkachuk R. Metod pobudovy biotexnichnoyi systemy dlya ocinyuvannya elektroretynogram $\mathrm{z}$ pidvyshhenymy virogidnistyu ta efektyvnistyu,"Visnyk TDTU", vol.14, pp.102$110,2009$.

[6] Tymkiv P.O., V.P. Zabytivskyj, B.I. Yavorskyj., Syntez filtru Kalmana dlya opracyuvannya nyzko intensyvnogo elektroretynosygnalu. "Vymiryuvalna ta obchyslyuvalna texnika $\mathrm{v}$ texnologichnyx procesax", Hmelnyczkyj, vol.1, pp.168-176, 2016

[7] Tymkiv Pavlo, Udoskonalennya metodu opracyuvannya nyzkointensyvnogo elektroretynosygnalu. „Teoretychni ta prykladni aspekty radiotexniky i pryladobuduvannya", T:TNTU, pp.123-125, June 2017.

[8] Tymkiv P.O., Veryfikaciya udoskonalenogo metodu vyznachennya koeficiyentiv filtru Kalmana u nyzkointensyvnij elektroretynografiyi, „Fundamentalni ta prykladni problemy suchasnyh texnologij", T.:TNTU, pp.22-23, May 2018.

[9] Dragan Ya.P., Hvostivskyj M.O., Shadrina G.M., Metod vyyavlennya elektropotencialnogo vidguku sitkivky oka u sumishi iz zavadamy, „Visnyk Ternopilskogo derzhavnogo texnichnogo universytetu", Ternopil: TDTU im. I.Pulyuya, vol. 1, pp. 136-141, 2007

[10] Rilk A.J. The Flicker Electroretinogram in Phase Space: Embeddings and Techniques, Aalen, 93p, 2003.

[11] Tkachuk R. A., Optymalna obrobka elektroretynosygnalu dlya vyznachennya formy elektroretynogramy, "Vymiryuvalna texnika ta metrologiya", vol. 70, pp. 9-13, 2009.

[12] R. Tkachuk, Metod pobudovy optymalnoyi obrobky elektroretynosygnalu ta ocinyuvannya virogidnosti yiyi rezultatu. Vymiryuvalna ta obchyslyuvalna texnika $\mathrm{v}$ texnologichnyx procesah, vol. 2. pp.156-162, 2008

[13] R.A. Tkachuk, Metod rekursyvnogo optymalnogo ocinyuvannya elektroretynogramy. "Information Extraction and Proces", Issue 31 (107), pp. 60-64, 2009.

[14] Tkachuk R., Matematychna model ta optymalna obrobka elektroetynosygnalu $\mathrm{v}$ zadachax oftalmodiagnostyky, "Visnyk TDTU", vol. 14, pp. 142-148, 2009.

[15] Leshchyshyn Yu.Z., Vyiavlennia periodychno korelovanoi variabelnosti sertsevoho rytmu za kryteriiem Neimana-Pirsona, "Kompiuterni tekhnolohii drukarstva", Lviv:Ukrainska akademiia drukarstva, vol. 18, pp. 214-211, 2007.

[16] Shakhtaryn B.Y. Obnaruzhenye syhnalov: ucheb. posobye. "M.:Helyos ARV", 488 p., 2006 